\title{
Johanna Georga Plerscha nieznany projekt ołtarza głównego $\omega$ kościele dominikanów $w$ Lublinie
}

Muzeum Narodowym w Warszawie, w dziale Rysunek Polski, w teczce z pracami Szymona Czechowicza znajduje się niedatowany, pozbawiony skali liniowej rysunkowy projekt nieokreślonego ołtarza wielkiego ${ }^{1}$ (ilustr. 1). W dolnym prawym rogu widnieje pod nim ewidentnie wtórny (XIX- lub XX-wieczny) podpis „Szymon Czechowicz”. Dodajmy od razu, że w rzeczywistości rysunek nie ma nic wspólnego z Czechowiczem, który nie jest znany z żadnych projektów małej architektury, a jego rysunki nie wykazują najmniejszego podobieństwa do omawianej pracy. Do kwestii atrybucji dzieła przyjdzie powrócić poniżej.

Omawiany rysunek, ostatnio konserwowany, jest nadniszczony i nosi ślady dość poważnych uszkodzeń - szereg miejsc jest wydartych. Obok kilku mniejszych dwie największe białe plamy po środku i po lewej stronie czynią nieczytelnymi dość ważne partie przedstawionego ołtarza: zwieńczenie cyborium i górną część lewej figury.

Rzeczony rysunek niewątpliwie przedstawia ołtarz główny; o tym, że nie jest to na przykład ołtarz boczny, świadczy stopień komplikacji jego architektury, ażurowy kształt, skala oraz obecność w polu głównym tabernakulum i tronu wystawienia/ cyborium. Jego struktura przestrzenna to wyraźnie ażurowa konstrukcja, otwierająca się w partii pola głównego i zwieńczenia na głębię, na nieokreślony drugi plan. Brak tu typowego obrazu ołtarzowego, a zamiast niego w przeźroczu środkowym znajduje się wielkich rozmiarów cyborium. Architektura ołtarza wspiera się na wysokim, dwustrefowym cokole i złożona jest $\mathrm{z}$ dwóch wiązek kompozytowych kolumn na tle filarów czy pilastrów, ustawionych nieznacznie ukośnie w stosunku do osi głównej. Z kolei na linii przeciw-ukośnej do owych podpór ustawiona została para bocznych bramek oraz wysuniętych silnie przed ich lico dodatkowych piedestałów, stanowiących optyczną kontynuację cokołu części środkowej. Bramki i piedestały zdobią rozbudowane grupy figuralne. Partia kolumnowa ołtarza otrzymała masywne belkowanie, nakryte charakterystyczną, zwężającą się trapezoidalnie

Muzeum Narodowe w Warszawie, Dział rysunku polskiego, sygn. Rys. Pol. 1181 122N/1104/15. 
TECHNE

TEXN H

SERIA NOWA

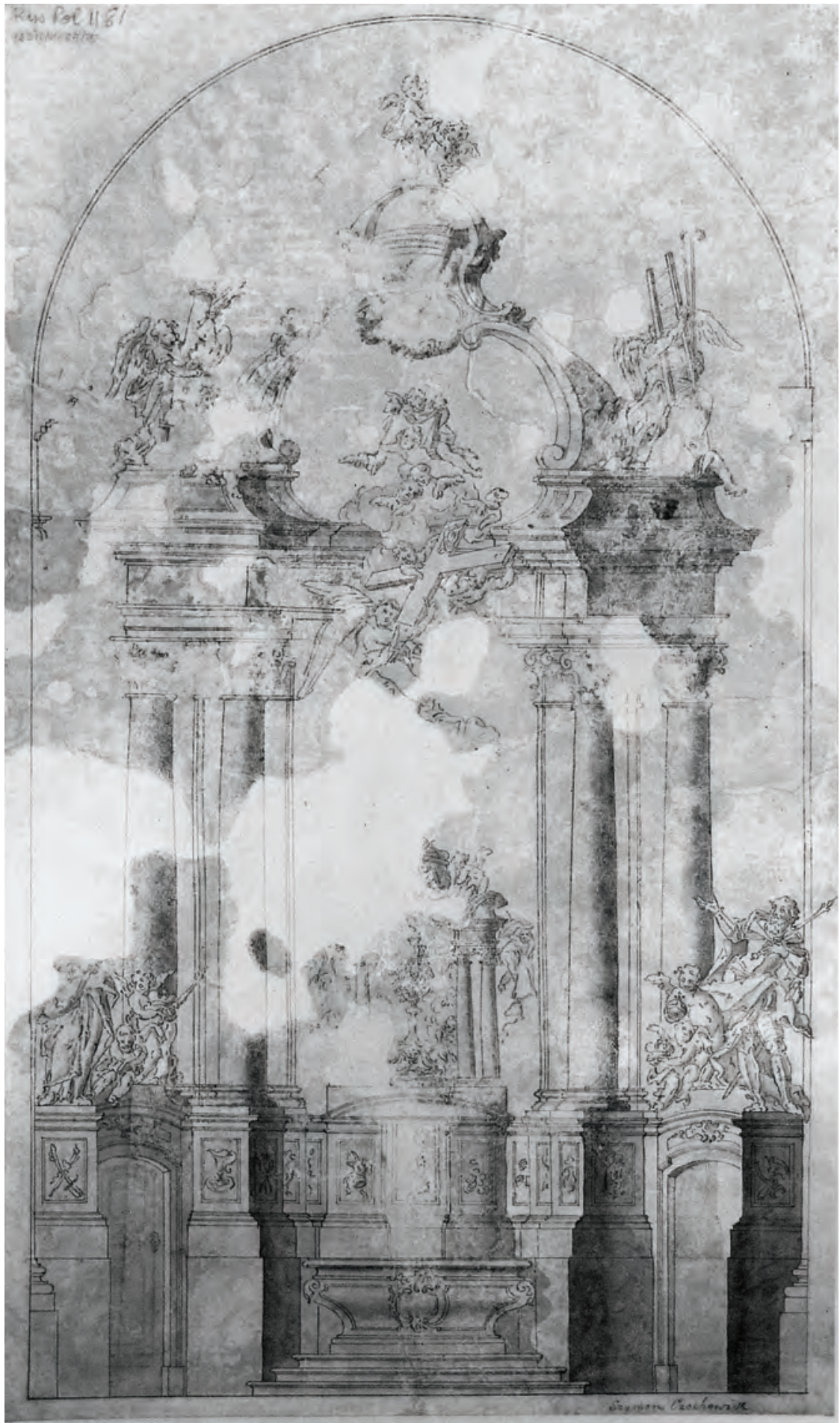

1. Johann Georg Plersch, projekt ołtarza głównego kościoła dominikanów w Lublinie, ok. 1747-1759, rysunek w: Warszawa, Muzeum Narodowe, Rys. Pol. 1181 122N/1104/15, fot. J. Sito 


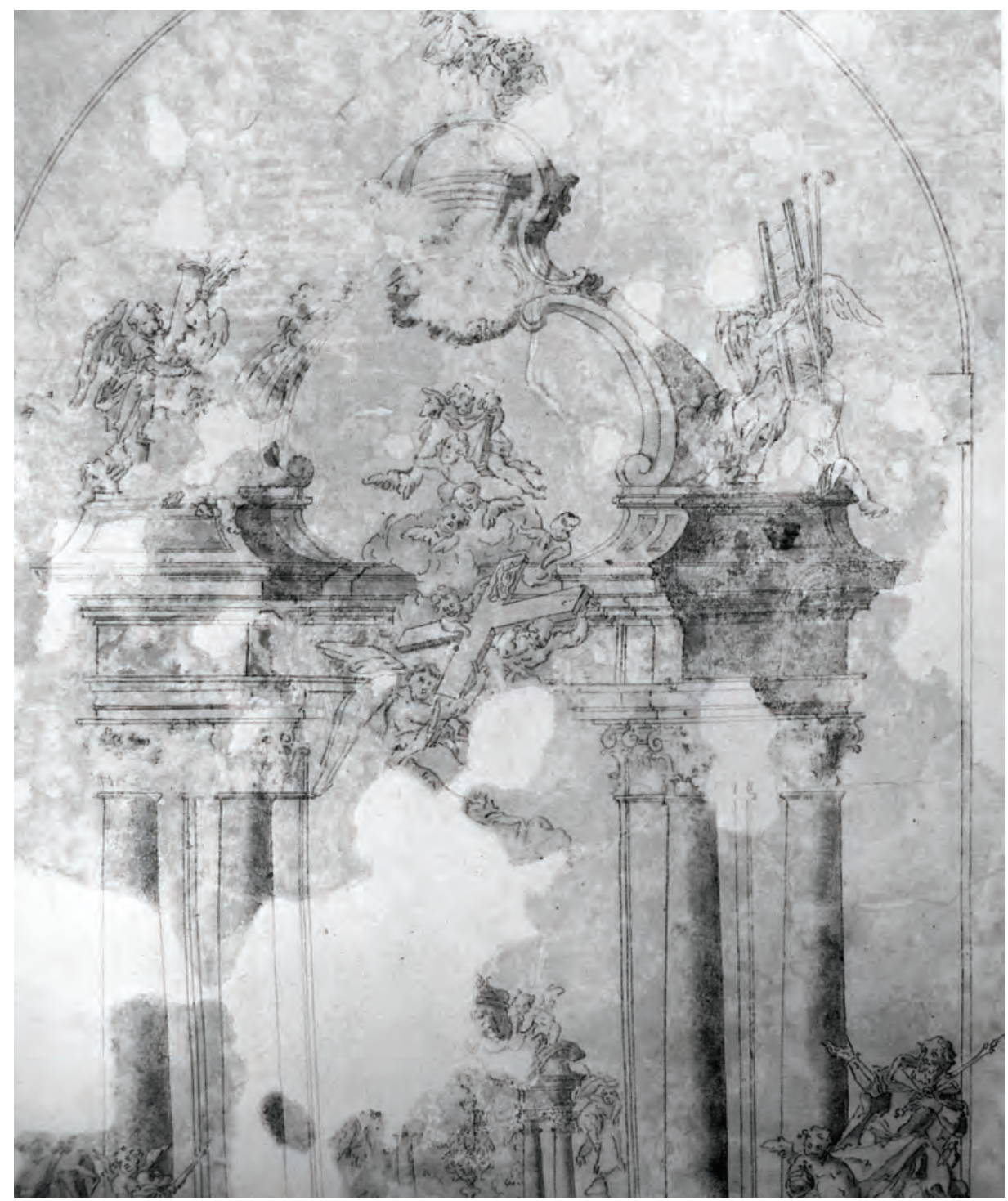

2. Johann Georg Plersch, projekt ołtarza głównego kościoła dominikanów w Lublinie (grupa aniołów z krzyżem), ok. 1747-1759, rysunek w: Warszawa, Muzeum Narodowe, Rys. Pol. 1181 122N/1104/15, fot. J. Sito

attyką o wklęsłych ściankach. Ażurowi pola głównego odpowiada mniejszy, owalny ażur zwieńczenia, utworzony przez ozdobnie wygięte kabłąki w typie perspektywicznie ujętych wolut, wspierających następne przeciwstawnie do nich ustawione woluty, przechodzące z kolei w rodzaj otwartej korony. Całe zwieńczenie uzyskało równie bogatą dekorację figuralną: rzeźby aniołów i aniołków z atrybutami niemal obsiadły tę partię architektury, stanowiąc optyczne przedłużenie pionów kolumn i cyborium. 
TECHNE

T E X N H

SERIA NOWA

Omawiany projekt jest wysokiej klasy. Architektura ma charakter proporcjonalny i harmonijny, dynamiczny, a zarazem „strukturalny”. Nacechowana jest wyjątkową elegancją, jest lekka, ażurowa, zarazem ma w sobie rys klasyczny przez zastosowanie kompozytowych kolumn, jak i fantazyjny, poprzez zastosowanie ukosów w rzucie, ażurów czy niezwykłych detali, jak kabłąki czy trapezoidalna attyka. Bogactwo rzeźby nie przesłania pierwszoplanowej roli struktury architektonicznej. To ważna uwaga, gdyż pozwala wskazać dość jednoznacznie na środowisko powstania dzieła, jakim była XVIII-wieczna Warszawa. Tu w projektach małej architektury zawsze uwidaczniała się przewaga struktury architektonicznej nad rzeźbą czy ornamentem, tu też najważniejsze koncepcje tego rodzaju wychodziły najczęściej od architektów, a jedynie realizowane były przez rzeźbiarzy, którym z kolei towarzyszyli stolarze, kamieniarze, sztukatorzy etc. ${ }^{2}$

Analizę ikonograficzną projektu zacznijmy od zwieńczenia, ponieważ to najlepiej zachowana partia rysunku a wszystkie przedstawienia są dość dobrze widoczne. W górnym przeźroczu anioły ulatujące wśród obłoków dźwigają wielki krzyż (ilustr. 2), wyraźnie prezentując go, ostentacyjnie okazując wiernemu, inne - ulatujące nieco niżej - czynią to z chustą św. Weroniki. Na odcinkach attyki kolejne anioły prezentują kolumnę ubiczowania oraz flagellum, a także drabinę, włócznię i gąbkę. Para puttów, wieńcząca stworzoną z wolut koronę ołtarza, okazuje gwoździe. Program skoncentrowany jest zatem na gloryfikacji Krzyża, a wraz z nim i innych arma passionis. Na tych samych treściach skupia się i dolna część ołtarza - filunki cokołów zdobią kolejne narzędzia Męki, tym razem płaskorzeźbione, wśród nich czytelne są: szabla Piotrowa, dzban z tacą, srebrniki Judasza, młotek i obcęgi.

Wobec powyższego nietrudno zgadnąć, kogo przedstawiają figury asystencyjne, także ta uszkodzona - to, rzecz jasna, para cesarskich propagatorów kultu Krzyża Świętego - na ich monarszy status wskazują regalia trzymane przez towarzyszące im putta. Po lewej stronie stoi cesarz Konstantyn (ilustr. 3) w nowożytnej (sic!) zbroi i płaszczu, wskazujący ręką na krzyż dźwigany przez anioły, zdając się obrazować swe zawołanie In Hoc Signo Vinces. Z kolei postać kobieca po lewej stronie to św. Helena, znalazczyni Verum Lignum Crucis i wielka czcicielka relikwii Krzyża. Zatem to właśnie relikwie Krzyża Świętego skrywa umieszczony centralnie relikwiarz, wstawiony w cyborium niczym monstrancja $\mathrm{z}$ Hostią w tronie wystawienia.

Rysunek nasz nie tylko nie posiada sygnatury ( $\mathrm{z}$ wyjątkiem wtórnego, bałamutnego podpisu) ani skali liniowej - nie zostało także określone miejsce przeznaczenia projektowanego ołtarza. Są jednak w ołtarzu obecne elementy umożliwiające jego niemal pewną lokalizację. Uwagę zwraca przede wszystkim przeanalizowana powyżej, wyszukana, skoncentrowana całkowicie na kulcie Krzyża ikonografia. Wskazywałaby ona na jeden z ośrodków szczególnego kultu relikwii Drzewa Krzyża. W Polsce istniało kilka takich ośrodków; obok klasztoru na Świętym Krzyżu, do najważniejszych należała świątynia dominikanów w Lublinie ${ }^{3}$. Skradziona w roku

Sito 2013, passim.

3 ZielińsKi 1887; DĘBIŃski 1895, s. 451; WADOWSKi 1907, s. 239, 240, 262-264, 271; KAPEĆ [bd.], s. 15, 16, 23; WojCiECHOWski 1995; KŁOCZOWski 2006, s. 25; WojCiECHOWsKi 2006, s. 140; Rolska-Boruch 2010; Rolska-BoruCH 2012, s. 599. 


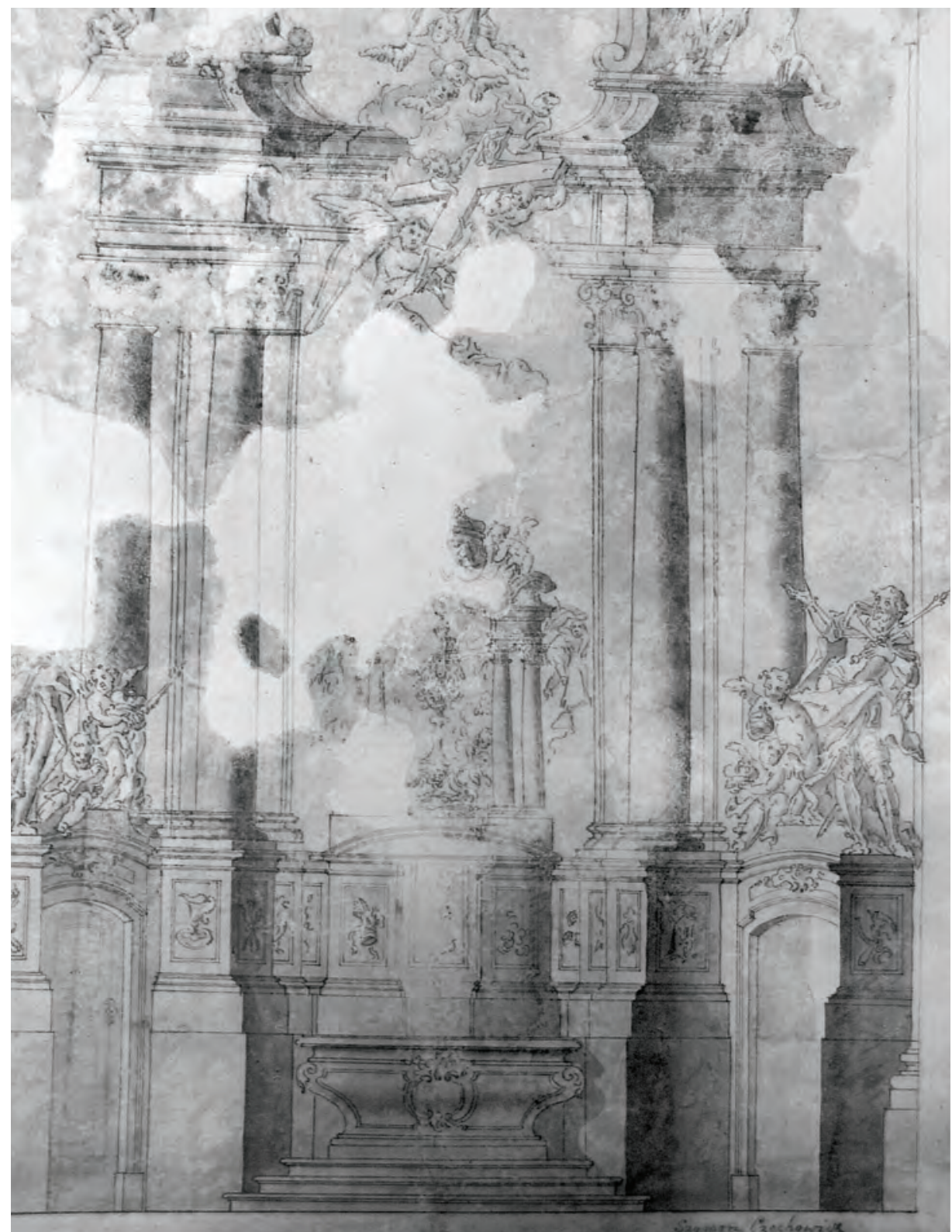

3. Johann Georg Plersch, projekt ołtarza głównego kościoła dominikanów w Lublinie (cyborium z relikwiarzem i cesarz Konstantyn), ok. 1747-1759, rysunek w: Warszawa, Muzeum Narodowe, Rys. Pol. 1181 122N/1104/15, fot. J. Sito

1991 i do dziś nieodnaleziona relikwia Drzewa Krzyża Świętego przez wieki skupiała na sobie niezwykły kult wiernych. Według zapisu Jana Długosza w Liber beneficiorum przywieźć ją miał do Lublina i przekazać pod opiekę Zakonu Kaznodziejskiego książę ruski Grzegorz za czasów panowania Kazimierza Wielkiego ${ }^{4}$.

4 DŁugosz 1860, s. 460-461. 
TECHNE

T E X N H

SERIA NOWA

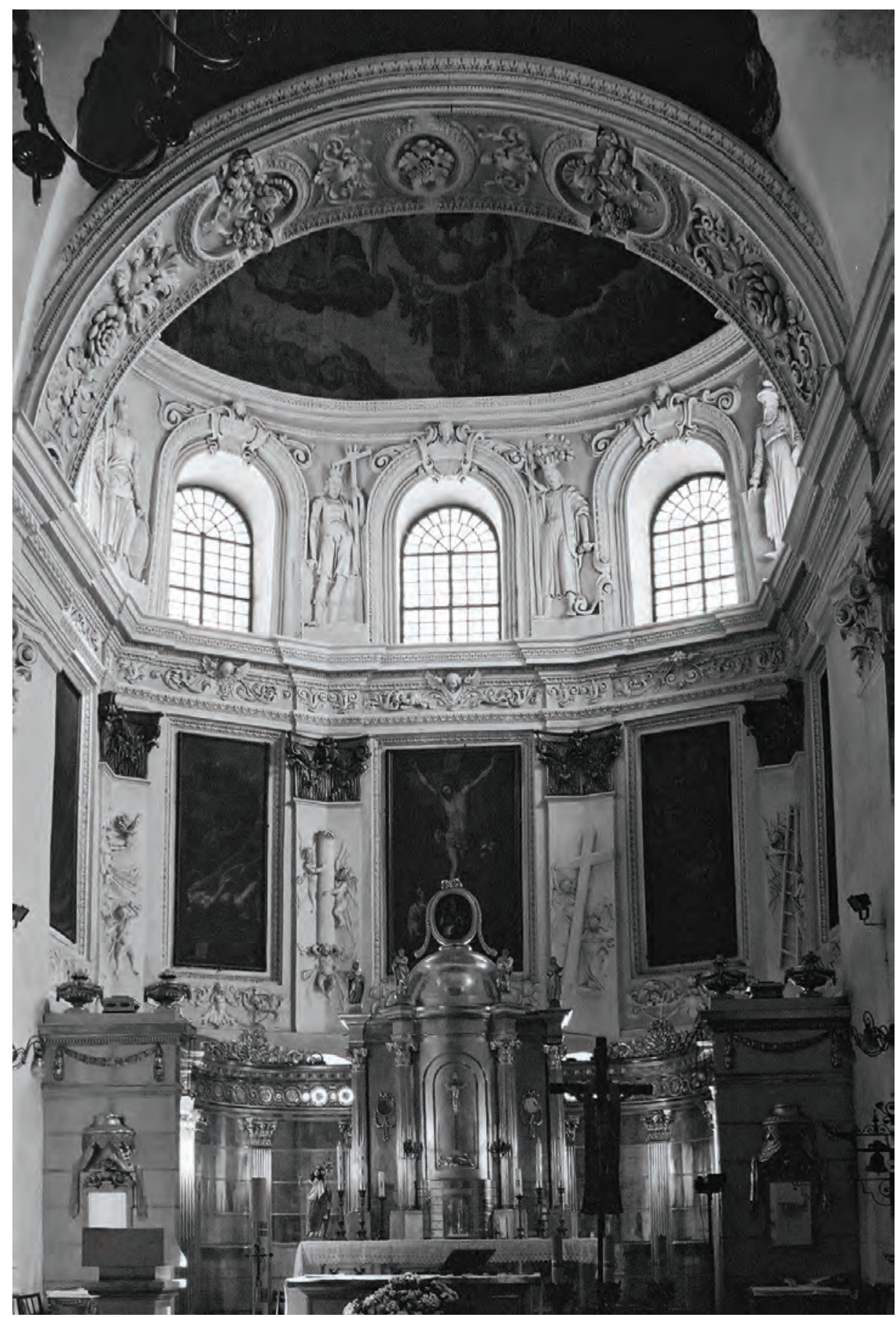

4. Lublin, kościół dominikanów, widok z prezbiterium na kaplicę Św. Krzyża (Tyszkiewiczów), fot. M. Wardzyński

Od czasu przywiezienia partykuły Krzyża stopniowo postępował rozwój lubelskiego klasztoru jako sanktuarium Drzewa Krzyża Świętego, a dominikańska świątynia stała się miejscem pielgrzymek mieszkańców miasta i okolic. Po pewnej sta- 
gnacji, związanej z reformacją i towarzyszącą jej ostrą krytyką nauczania i praktyk Kościoła katolickiego w zakresie kultu relikwii, w końcu XVI wieku rozpoczęło się odrodzenie zarówno kultu, jak i znaczenia samego konwentu 5 . Największy jego rozwój trwał od początku drugiej dekady do lat 70. XVII wieku. W dziejach świętej partykuły znalazły odzwierciedlenie wszystkie kolejne zagrożenia bytu miasta i Rzeczypospolitej: powstanie Chmielnickiego, potop szwedzki i najazd rosyjski ${ }^{6}$. W roku 1648 właśnie relikwia Krzyża Świętego miała uchronić miasto przed atakiem wojsk Chmielnickiego. Wiara w jej opiekuńcze oddziaływanie utrwaliła się w następnych latach, przy czym traktowano ją wówczas jako palladium Królestwa?

Dla zapewnienia świętej relikwii godnej oprawy architektonicznej gotycki kościół dominikański przeszedł w końcu wieku XVI i w kolejnym stuleciu gruntowne przekształcenie, najpierw w 1591 roku według projektu Pawła Negroniego, potem zaś w połowie XVII wieku, kiedy to powstało kilka towarzyszących świątyni kaplic. Jedną z nich jest - mieszcząca przez lata relikwie Krzyża Świętego - okazała kaplica Tyszkiewiczów, stanowiąca jednocześnie chór zakonny, a zbudowana na osi prezbiterium w latach 1645-1654 przez cechmistrza muratorów lubelskich Jana Cangerle’a, z fundacji Janusza Tyszkiewicza, wojewody kijowskiego ${ }^{8}$ (ilustr. 4). Olbrzymia, rozświetlona rzędem okien kaplica na planie wieloboku została nakryta wielką kopułą i uzyskała wspaniały wystrój i wyposażenie wnętrza, obok stiuków Giovanniego Battisty Falconiego ${ }^{9}$, fresk w kopule i serię sztalugowych obrazów naściennych autorstwa Tomasza Muszyńskiego ${ }^{10}$. Zarówno dekoracja plastyczna, jak i malowidła gloryfikowały Mękę Pańską. Ośrodkiem tej dekoracji był umieszczony dokładnie na osi prezbiterium obraz Ukrzyżowania ${ }^{11}$. Od prezbiterium rzeczoną kaplicę oddzielała wielka półkolista arkada opięta po bokach pilastrami.

Zarówno sytuacja, w jakiej umiejscowiony został ołtarz z omawianego rysunku (ażurowość i otwarcie ołtarza na głębię przestrzenną), jak i otaczająca go, wrysowana na projekcie zastana architektura są bardzo zbliżone do realiów wnętrza kościoła lubelskich dominikanów. Otwarcie perspektywiczne pola głównego sugeruje istnienie drugiego planu; można przyjąć, że był nim chór zakonny czy właśnie sprzężona osiowo z prezbiterium kaplica. Poświęcona kultowi Krzyża ikonografia ołtarza byłaby zatem w pełni zgodna z kontekstem Tyszkiewiczowskiej kaplicy Świętego

\footnotetext{
5 Ruszel 1655, s. nlb.

6 W 1655 roku Lublin został zajęty przez wojska moskiewskie, a relikwie Krzyża Świętego przewiezione do Moskwy i umieszczone w soborze Uspieńskim, zwrócone dopiero po pokoju andruszowskim w 1667 roku (Kossowski 1958, s. 234, 249; RolsKa-BorUch 2010, s. 108).

Wojciechowski 2006, s. 138-146.

8 WAdowski 1907, s. 218, 223-224, 242-244; MiŁobęDZKi 1980, s. 309-310; RolsKa-Boruch 2010, s. 104-109 (na s. 108 informacja, że budowę po śmierci Tyszkiewicza wsparła jego siostra Krystyna Jelec, a później Stanisław Witowski); SzewCzy K-Prokurat 2012, s. 24-26.

9 Kowalczyк 1962, passim.

10 Eustachiewicz 1956-1957, s. 227-240; KowalCzy 1962, s. 30.

11 Bohdziewicz 1954, s. 288; Eustachiewicz 1956-1957, s. 228; Gawarecki 1959, s. 67-68; Kowalczyk 1962, s. 30, 35; Rolska-Boruch 2010, s. 106.
} 


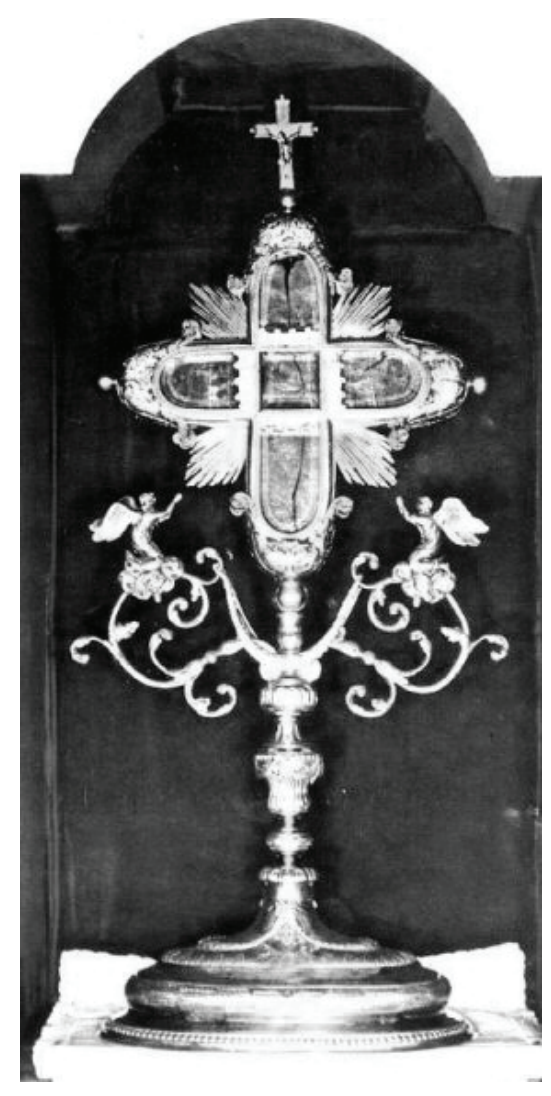

5. Adam Goworkowic i mistrz Hanus, relikwiarz Drzewa Krzyża Św. z kościoła dominikanów w Lublinie, 1640-1645, (zaginiony), (wg http://www.lublin.dominikanie. $\mathrm{pl} /$ ?s=28id=34, dostęp $\times$ 2018)

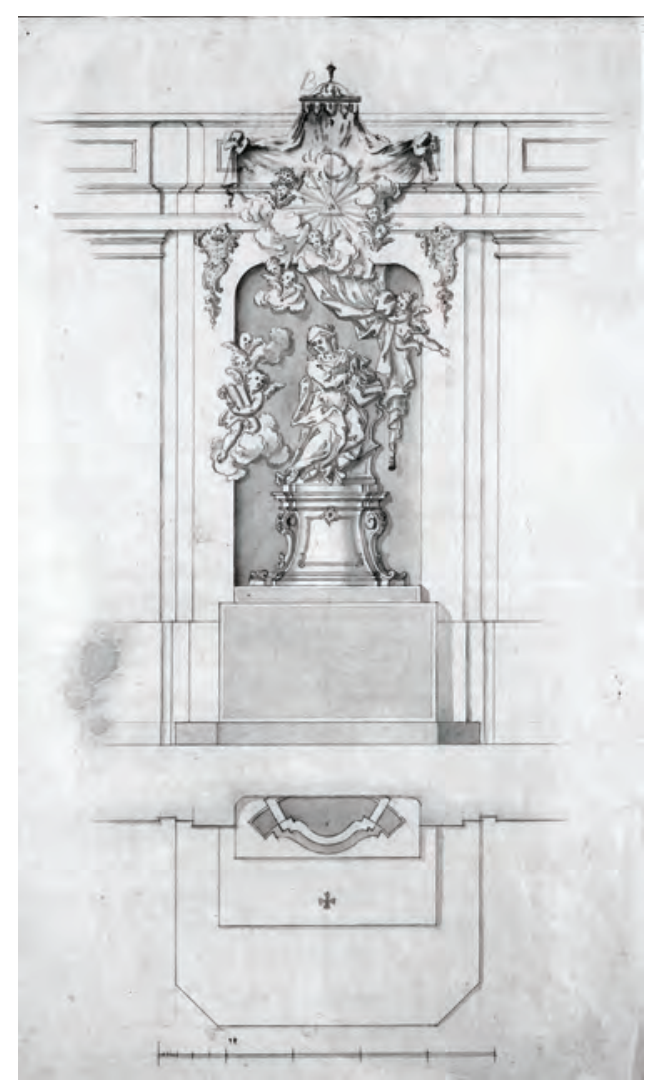

6. Johann Georg Plersch, projekt ołtarza bocznego w kaplicy Pałacu Saskiego w Warszawie, ok. 1744, rysunek w: Drezno, Sächsisches Hauptstaatsarchiv, S. VII, F. 89, Nr. $5 z$

Krzyża $^{12}$, zaś drugi plan dla arkadowego przeźrocza stanowiłby wspomniany obraz Ukrzyżowania pędzla Tomasza Muszyńskiego. Jednak kluczowym dowodem na przeznaczenie naszego projektu ołtarza właśnie do Lublina jest obecność na rysunku - w cyborium ponad tabernakulum - relikwiarza Drzewa Krzyża Świętego o identycznym kształcie jak zachowany do czasu ostatniej kradzieży XVII-wieczny relikwiarz o wydłużonych zakończonych półkoliście ramionach i bogatej puklowanej stopie $^{13}$ (ilustr. 5).

Omawiany rysunkowy projekt $\mathrm{z}$ warszawskiego Muzeum Narodowego wykazuje wszelkie cechy stylu rysunkowego Johanna Georga Plerscha (ok. 1700-1774) ${ }^{14}$, najwybitniejszego rzeźbiarza warszawskiego doby późnego baroku, parającego się

\footnotetext{
12 Kowalczyk 1962, s. 35; Rolska-Boruch 2010, s. 106-109.

13 Wzorek 1971, s. 68-69; RolsKa-Boruch 2010, s. 102-104.

14 Sito 2013, s. 151-303 (rozdział Wielki warsztat nadworny Johanna Georga Plerscha), tamże wcześniejsza literatura, spośród której wyróżnia się biogram: МıкоскA-RACHUвоWA 2003.
} 


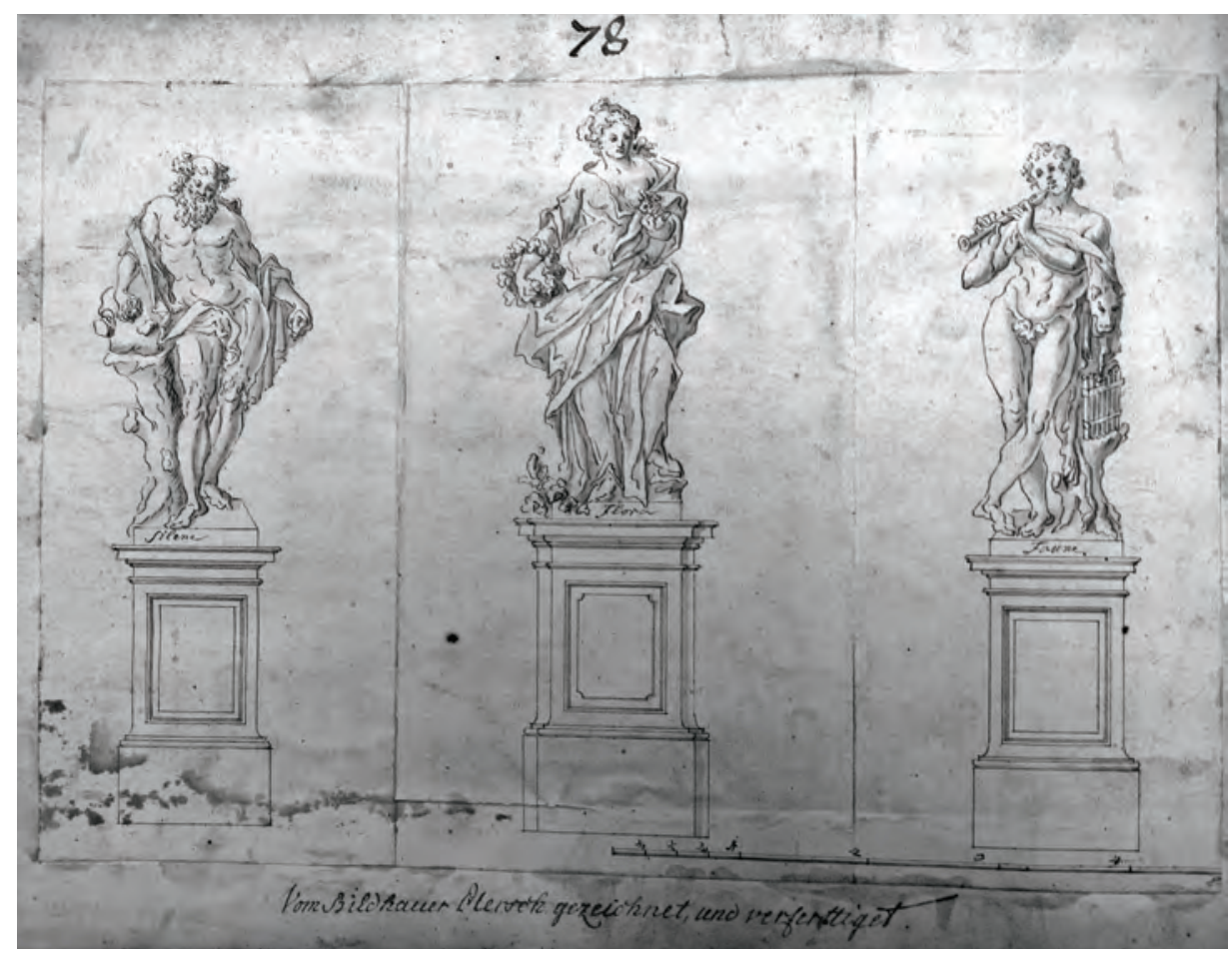

7. Johann Georg Plersch, projekt rzeźb Flory, Sylena i Fauna do Ogrodu Saskiego w Warszawie, ok. 1740 rysunek w: Drezno, Sächsisches Hauptstaatsarchiv, S. VII, F. 89, Nr. $5 z$

także projektowaniem małej architektury ${ }^{15}$. Porównanie z jego kilkoma zachowanymi rysunkami, jak ołtarze kaplicy Pałacu Saskiego (ilustr. 6), figury mitologiczne z Ogrodu Saskiego (ilustr. 7), pomnik św. Jana Nepomucena przy Placu Trzech Krzyży w Warszawie czy figura św. Józefa z parku królewskiego pałacu w Piasecznie ${ }^{16}$, czyni ową atrybucję niemal pewną. Plersch jako rysownik odznaczał się szczególnym upodobaniem do charakterystycznej, nerwowej kreski, do głęboko, po rzeźbiarsku wydobywanego malowniczego modelunku i jakby szkicowego charakteru projektowanych figur, co w pełni widoczne jest na prezentowanym rysunku. Szczególna właśnie dla Plerscha jest, obecna tu, charakterystyczna odmiana ornamentu rocaille, kompozycja figur i ich fizjonomia, a także owiewająca postaci ludzkie specyficzna aura. Niektóre partie architektoniczne, na przykład cokoły, bliskie są innym projektom ołtarzowym Plerscha (kaplica Pałacu Saskiego).

Rysunek lubelskiego ołtarza można ostrożnie datować na dekady około połowy XVIII wieku. Wskazuje na to choćby typ dojrzałego ornamentu rocaille, który na dobre rozgościł się w dekoracji stosowanej w środowisku warszawskim od początku

\footnotetext{
15 Na ten mało znany i rzadko poruszany temat: Siтo 2013, s. 187-188, 263-264, 295-301, a także: Siтo 2019 (artykuł złożony do druku w „Biuletynie Historii Sztuki”).

16 Siтo 2013, s. 187-188, 263-264, 295-301.
} 
TECHNE

T E X N H

SERIA NOWA

lat 40. XVIII wieku ${ }^{17}$. Z kolei wskazywane jako analogiczne projekty bocznych ołtarzy w kaplicy Pałacu Saskiego pochodzą na przykład z 1744 roku. Wyprzedzając dalsze rozważania niniejszego studium, czas powstania projektu naszego można doprecyzować: musiał on powstać po roku 1747, a przed 1760.

Projekt Plerscha ma w sobie niewątpliwie wiele $\mathrm{z}$ architektury rzymskiej. $\mathrm{Z}$ tej tradycji wywodzi się silnie strukturalny, a przy tym dynamiczny jego kształt ogólny, zasadniczo rzymskie jest użycie zmasowanych kolumn, z rzymską tradycją można wiązać jego swoistą „mięsistość”, monumentalizm i scenograficzny charakter architektury oraz teatralność sztafażu figuralnego. Bliższa analiza pozwala jednak wskazać także na silne zależności omawianego projektu od sztuki nowożytnej Francji. Szczególnie mocno w tradycji francuskiej zakorzenione jest baldachimowe rozwiązanie zwieńczenia, z jakiego szczególnym wariantem mamy do czynienia na rysunku Plerscha. Inspirowane zasadniczo baldachimem Berniniego, nad Sekwaną tego rodzaju rozwiązania pojawiały się już w połowie wieku XVII. Należały do nich wzornikowe propozycje Jeane’a Le Pautre’a ${ }^{18}$ czy słynne ołtarze z Val-de-Grâce i kaplicy królewskiej w kompleksie Les Invalides. Wczesnymi przykładami XVIII-wiecznymi różnych wariantów baldachimów są projekty Roberta de Cotte’a dla katedry Notre Dame w Paryżu, ołtarz główny kościoła Saint-Germain-des-Prés czy projekt Jean-François Blondela na ołtarz w kościele Saint-Jean-en-Grève z 1720 roku $^{19}$.

W pierwszej połowie XVIII wieku we Francji zaczęły się licznie pojawiać tworzone $\mathrm{z}$ rozmachem ołtarze baldachimowe na dynamicznych planach wycinka koła, wycinka lub polowy elipsy, stanowiące wariacje tych wcześniejszych. Do najlepszych należą projekty opublikowane w 1747 r. przez Jeana-François de Neufforge'a w kompendium Nouveaux Livres de plusieurs Projets d'Autels et Baldaquins ${ }^{20}$. Młody Neufforge - znany przede wszystkim z późniejszych, inspirujących także Polaków prac neoklasycystycznych - objawia się w zupełnie innym wcieleniu, jako architekt francuskiego rokoka, zabarwionego wprawdzie sztuką rzymską, ale w gruncie rzeczy zdecydowanie samodzielnego formalnie. Koncepcje Neufforge’a (ilustr. 8-9) ukazują lekkie, przesycone światłem i powietrzem projekty wolnostojących ołtarzy z użyciem wiązek kolumn i giętych elegancko kabłąkowych „napowietrznych” baldachimów, tworzących ażury w miejsce tradycyjnych masywnych zwieńczeń. Analogie do projektu Plerscha wydają się tu silne. Dodatkowo wzmacnia je użycie zwężającej się ku górze attyki o wklęsłych ściankach.

Ów typ Neufforge’owskiego ołtarza wolnostojącego Plersch z jednej strony wiernie podjął, z drugiej jednak przetransponował, adaptując do warunków miejscowych. Projektant zdecydował się bowiem nie tyle na ołtarz wolnostojący, izolowany w dookolnej przestrzeni, lecz na nieco odmienny w charakterze ołtarz

\footnotetext{
Na ten temat: Siтo 2013, s. 251-253.

PrÉAud 1999, s. 312-320.

PÉrouse 1995, s. 327-377

Neufforge 1747.
} 


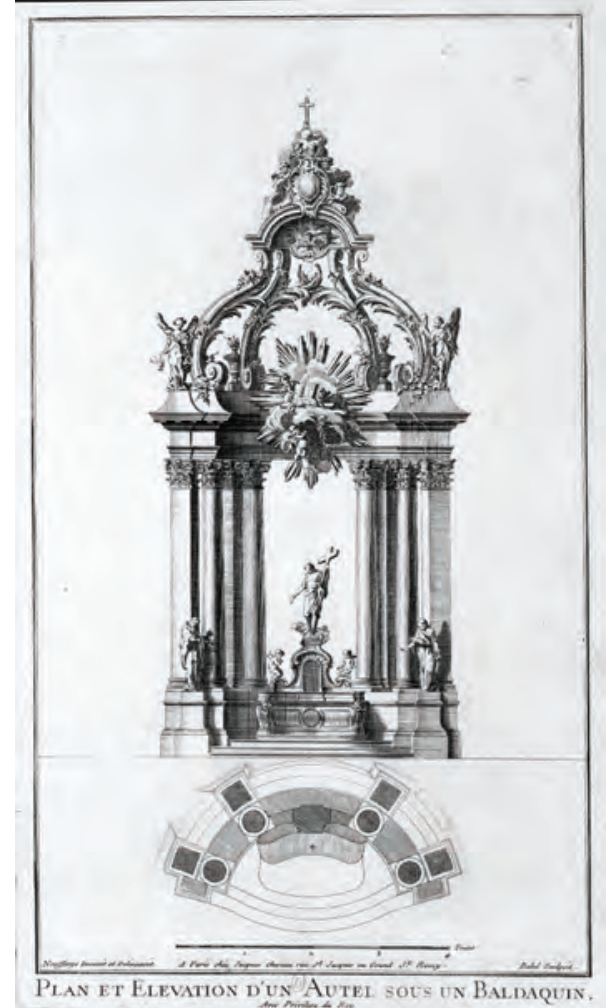

8. Jean-François de Neufforge, Nouveaux Liures de plusieurs Projets d'Autels et Baldaquins, Paris 1747, tabl. 1

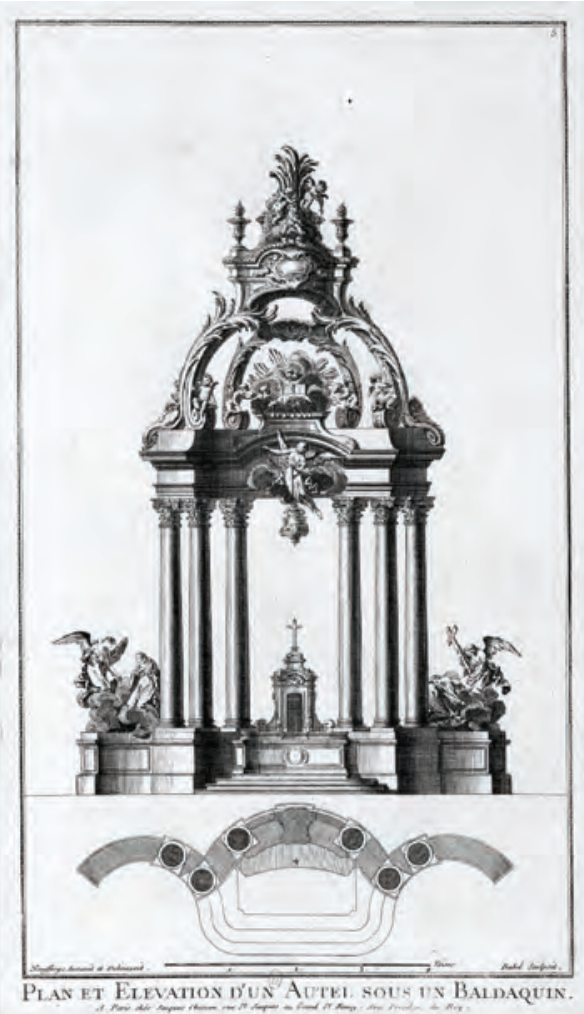

9. Jean-François de Neufforge, Nouveaux Liures de plusieurs Projets d'Autels et Baldaquins, Paris 1747, tabl. 6

„przegrodowy”21, pomyślany jako rodzaj potężnej kulisy odgradzającej prezbiterium od przestrzeni kaplicy mieszczącej chór zakonny. Zarzucił więc pierwotny plan eliptyczny czy też oparty na kombinacji wycinków elips - taka komplikacja przestrzenna nie była bowiem w Lublinie potrzebna - a wzór francuski potraktował nade wszystko w kategoriach elewacji.

Pod względem swobodnego posługiwania się wzorami francuskimi, a zarazem stapiania ich w jedno z rzymską tradycją architektury, Plersch - domniemany projektant naszego ołtarza - pozostaje nieodrodnym uczniem i wychowankiem Jakuba Fontany ${ }^{22}$, swego szwagra i partnera w przedsięwzięciach artystyczno-budowlanych, bywalca paryskich atteliers w czasie swych kilkukrotnych pobytów w państwie Ludwika XV (co najmniej w latach 1731-1732 i w 1747 roku) ${ }^{23}$. Bardzo bliski

\footnotetext{
21 Niemieckie pojęcie „Scheidewandnaltar” zostało omówione w: Sito 1999 (tamże literatura).

22 Bartczakowa 1970; Sito 2013, s. 265-301 (rozdział: Jakub Fontana i Johann Georg Plersch - spółka architektoniczno-rzeźbiarska); Wyszomirska 2016, s. 131-137.

23 Gajewski 2012, s. 58-91; Sito 2013, s. 267-269. Na powtórny pobyt w Paryżu Jakuba Fontany w 1747 r. w charakterze towarzysza podróży dyplomatycznej marszałka wielkiego koronnego Franciszka Bielińskiego wskazano w: Wyszomirska 2016, s. 132.
} 


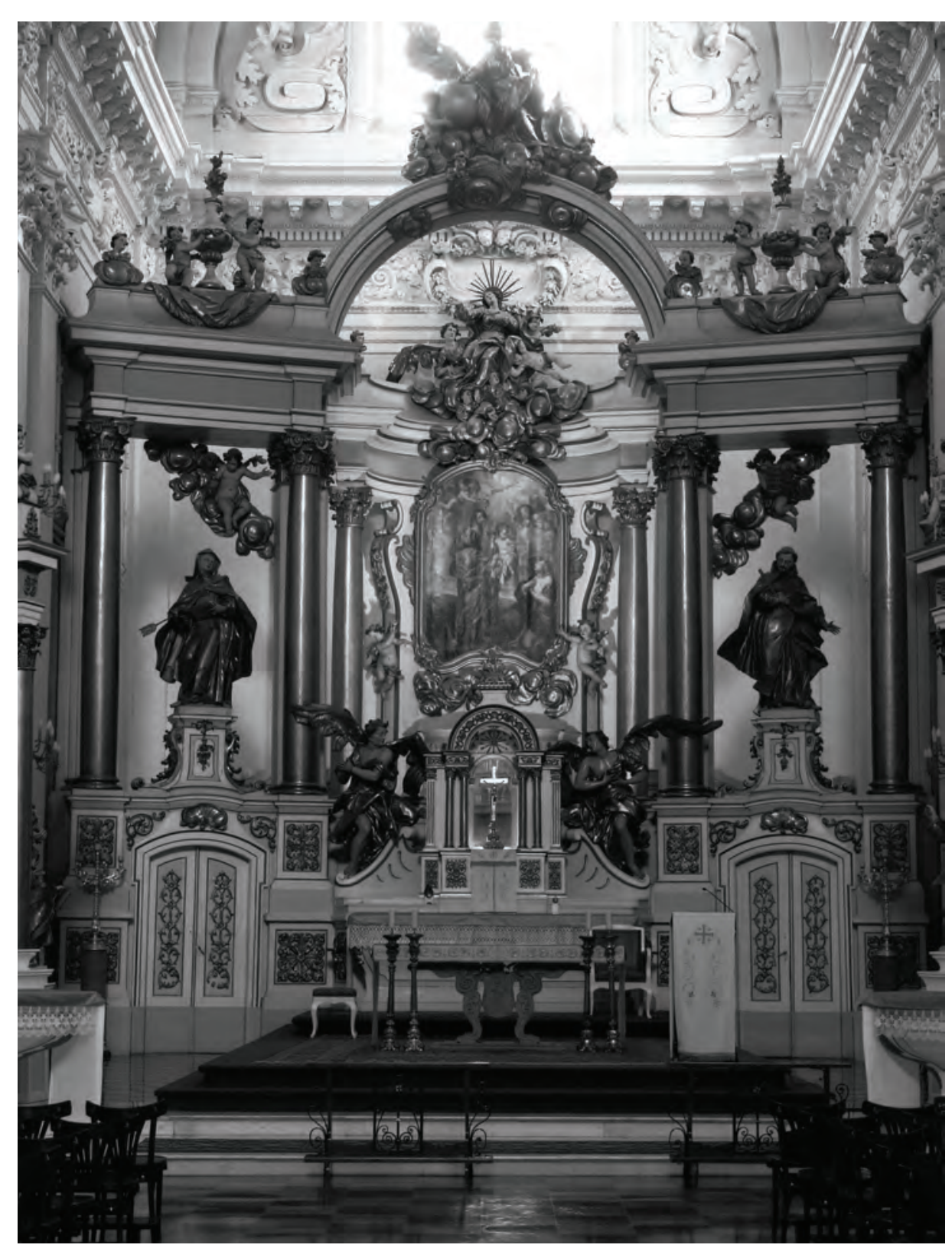

10. Jakub Fontana (projekt), Johann Georg Plersch (wykonanie), ołtarz główny kościoła karmelitów bosych $w$ Warszawie, 1749, fot. J. Sito

projektowo omawianemu rysunkowi jest choćby ołtarz główny kościoła karmelitów bosych w Warszawie z 1749 roku (projektu Jakuba Fontany), którego Plersch był wykonawcą (ilustr. 10). Czerpał on inspiracje z dzieł graficznych nadwornego architekta księcia Filipa Burbona-Orleańskiego, Gilles-Marie Oppenorda ${ }^{24}$. Lekkość, ażurowość, przesycenie powietrzem i światłem, punktowa koncentracja dekoracji

24 OEUVRES 1749-1751 [jako serie rycin publikowane przed 1723]; Sito 2013, s. 274-276. 


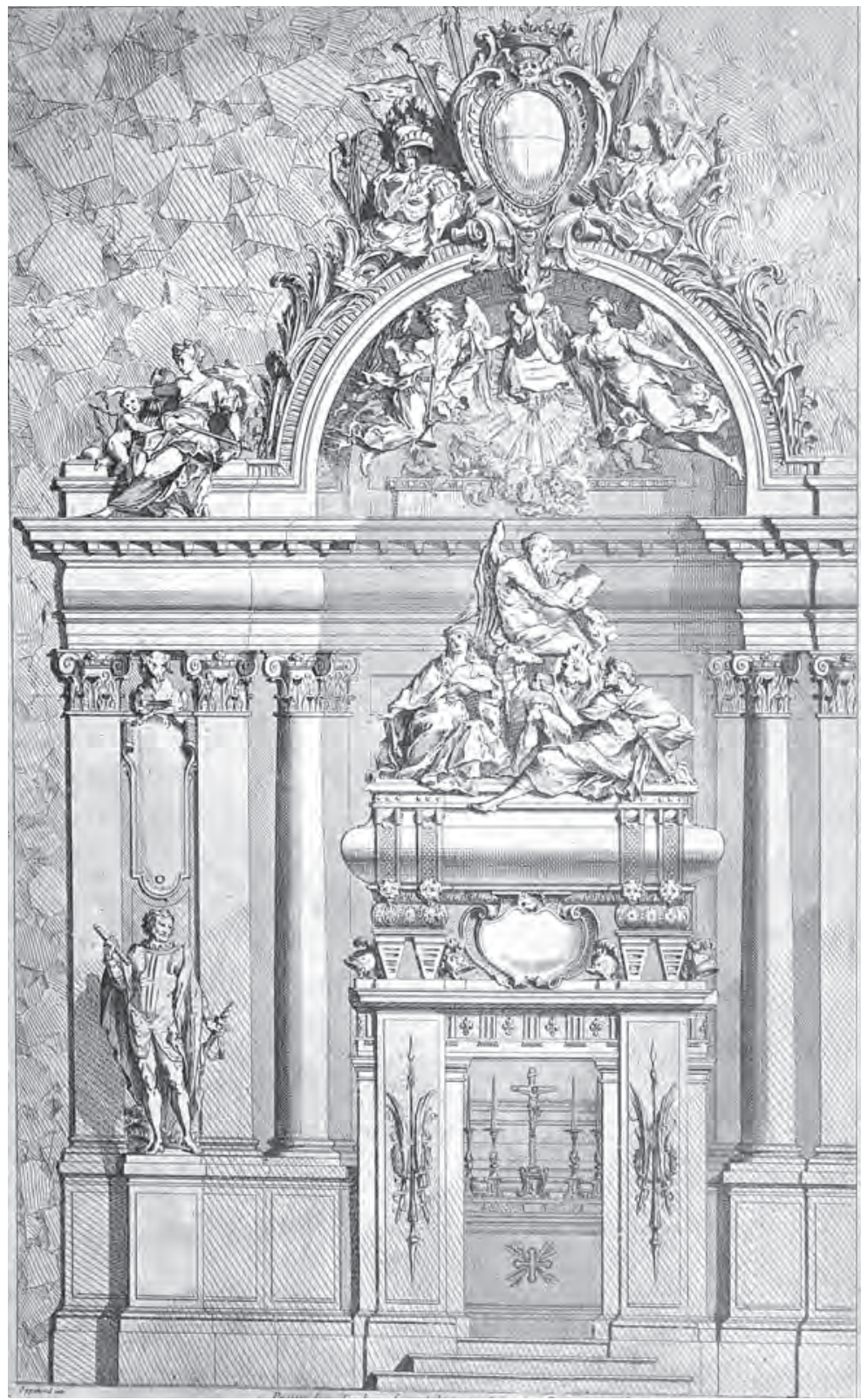

11. Gilles-Marie Oppenord, projekt nagrobka-portalu kaplicy, [w:] Oeuures de [...] Ecuier Directeur General des Batiments et jardins de son Altesse Royale Monseigneur Le Duc d'Orleans Regent de Royaume [...], Paris 1749-1751 lub w serii rycin publikowanych przed 1723, tabl. CXV

rzeźbiarskiej, ponadto użycie wybitnie francuskiego motywu serliany zbliża kompozycje warszawską i lubelską do pomysłów francuskich (ilustr. 11).

Jako architekt Plersch nie wychodził w zasadzie poza lekcję odebraną od Jakuba Fontany ${ }^{25}$. Czy to w projektach ołtarzy do kaplicy Pałacu Saskiego, czy w przypadku

25 Sito 2019, s. 265-301. 
omawianego rysunku do Lublina zajmujący się projektowaniem rzeźbiarz trzyma się ściśle Fontanowskiego idiomu. Dynamiczny, wolutowy piedestał, system proporcji cokołów czy zamknięte ćwierćkoliście bramki, pałacowe w typie, wywodzą się przecież z języka projektów Fontany. Można być zatem niemal pewnym, że i w przypadku Neufforge’a podpowiedź co do inspiracji popłynęła od obeznanego z nowinkami francuskimi warszawskiego architekta. Inna sprawa to chłonność, jaką wobec wszelkich nowinek wykazywał się Plersch - wychowany przecież zasadniczo na wzorach zupełnie od francuskich odmiennych, bo rzymskich i środkowoeuropejskich - i to jak znakomicie, m.in. dzięki użyciu tak wyszukanego wzoru, jak projekty Neufforge’a, poradził sobie z trudnym wyzwaniem przestrzennym lubelskiej świątyni.

Omawiany rysunek przedstawia zatem projekt ołtarza głównego dla świątyni dominikanów w Lublinie. Jak ma się jednak owa konstatacja do wiedzy przekazanej przez literaturę, pozostającej z nią w całkowitej sprzeczności? Przypomnijmy bowiem, co na temat lubelskiego dzieła, jego projektu i realizacji pisali Ambroży Wadowski $^{26}$, Józef Lepiarczyk ${ }^{27}$, Władysław Tatarkiewicz ${ }^{28}$ i Jerzy Kowalczyk ${ }^{29}$, dwaj pierwsi w oparciu o źródła archiwalne. Trzeba tu jasno stwierdzić, że archiwalia - wbrew powyższym rozważaniom - nie wspominają ani o Plerschu jako autorze projektu czy wykonania, ani o Warszawie jako o miejscu złożenia zamówienia. W ich świetle projektantem lubelskiego ołtarza miałby być krakowski architekt Francesco Placidi, zaś miejscem realizacji kamiennej (!) struktury - podkrakowski Dębnik.

Posłużmy się bezpośrednimi cytatami źródłowymi. Jeszcze w 1742 roku wybitny krakowski architekt Francesco Placidi w liście do biskupa krakowskiego i kanclerza wielkiego koronnego Andrzeja Stanisława Kostki Załuskiego pisał:

a Lublino, ove sono stato questi giorni a dietro un altare maggiore alli patri domenicani dedicato all S. Legno della Croce isolato nel mezzo del Coro, di marmi dell paese che costera in circa 50 mille florinij

w Lublinie (...) byłem w tych dniach w sprawie ołtarza wielkiego dla ojców dominikanów, dedykowanego Drzewu Krzyża Świętego, ustawionego pośrodku chóru, [wykonanego] z marmurów krajowych, który będzie kosztować około 50 tysięcy złotych ${ }^{30}$.

\footnotetext{
26 WAdOWski 1907, s. 349-352.

27 LEPIARCZYK 1965, s. 72-73, 81-82.

28 TATARKiEWICZ 1952, s. 150.

29 KOWALCZYK 1992, s. 109.

30 Biblioteka Narodowa w Warszawie, Korespondencja Andrzeja Stanisława Załuskiego z roku 1742, t. 2 [L-Z], rkps 3223 III, k. 102-103 (list Francesca Placidiego do bpa Andrzeja Stanisława Kostki Załuskiego), wg: LePIARCZyk 1965, s. 72-73, 81-82.
} 
Sprawa wykonawstwa ołtarza dominikańskiego miała się znacznie przeciągnąć w czasie. Dopiero po 18 latach, w lutym 1760 roku, zawarty został, bardzo ciekawy w swym brzmieniu, kontrakt „między O. Józefem od św. Eliasza, karmelitą, przeorem OO. Karmelitów w Czerny i Tomaszem Góreckim, góry marmurowej Czernej magistrem [kamieniarzem], a klasztorem lubelskim" o wykonanie robót marmurowych: „balustrady, mensy z cyborium i portierami [oraz] wielkiego ołtarza przy ścianie chórowej" i dostawienie ich do Wisły za 26 tys. złotych polskich oraz ustawienie ich na miejscu za odrębną zapłatą z zastrzeżeniem

iż ta wszystka robota marmurowa powinna być według planty i abrysu kształtnie, ozdobnie i fundamentalnie od Pana magistra wystawiona, na co modelusze na wszystkie gzemsy, filunki, kroksztyny, bazy i inne mają być providowane od Imć Pana architekta Placydego, a przytem za lat dwa ma być wykonana robota, wypłacenie zaś należności ma nastąpić $\mathrm{w}$ siedmiu ratach w tym przeciągu czasu, ostatnia przy wykończeniu robót ${ }^{31}$.

Treść kontraktu wskazuje, że z Francesco Placidi, przywoływany tu jako projektant, mając do dyspozycji zastaną, nader specyficzną przestrzeń kościoła w Lublinie, z prezbiterium zakończonym kaplicą Świętego Krzyża, pełniącą rolę chóru zakonnego, planował zupełnie inne rozwiązanie ołtarza niż przedstawiony wyżej projekt Plerscha. Rozwiązanie owo, głęboko przestrzenne, pozostawało w ścisłym związku z XVII-wieczną jeszcze tradycją karmelitańską - znaną choćby z Czernej, z kościoła na Wesołej w Krakowie (ilustr. 12), ze Lwowa czy Przemyśla - zgodnie z którą ku przodowi wysunięte było cyborium z bramkami po bokach (tu nazwanymi „portierami”), stanowiąc niejako pierwszy plan, zaś samo retabulum ołtarzowe miało być umieszczone głębiej, widniejąc na drugim planie. To ostatnie zazwyczaj umieszczano przy ścianie szczytowej prezbiterium, w Lublinie miało być ono ustawione w kaplicy Tyszkiewiczów, przy ścianie.

Różnica między rozwiązaniem zastosowanym przez Placidiego i tym z rysunku Plerscha jest oczywista, mimo że oba projekty pozostają silnie przestrzenne. Dwuplanowa koncepcja Plerscha odbiega od tradycyjnego, w istocie wczesnobarokowego rozwiązania karmelitańskiego z niskim pierwszym i wysokim drugim planem i nawiązuje do nowatorskich, perspektywicznych (kulisowych) ołtarzy warszawskich w silnie teatralizującym duchu Andrei Pozza, w rodzaju ołtarza w kościele bernardynów św. Anny z ok. 1730 (ilustr. 13) czy karmelitów bosych z 1749 roku²

Na początku 1761 roku prace nad lubelskim ołtarzem projektu Placidiego były już w wielkiej części ukończone przez kamieniarza Tomasza Góreckiego, o czym

\footnotetext{
31 Kontrakt ów, pochodzący z dawnego klasztoru dominikanów w Lublinie, w początku XX w. znajdujący się w rękach prywatnych, dziś najpewniej zaginiony, odpisał w większych fragmentach Ambroży Wadowski (WADowski 1907, s. 350-351)

32 Sito 1999, s. 245, 250-255.
} 


\section{TECHNE \\ T E X N H \\ SERIA NOWA}

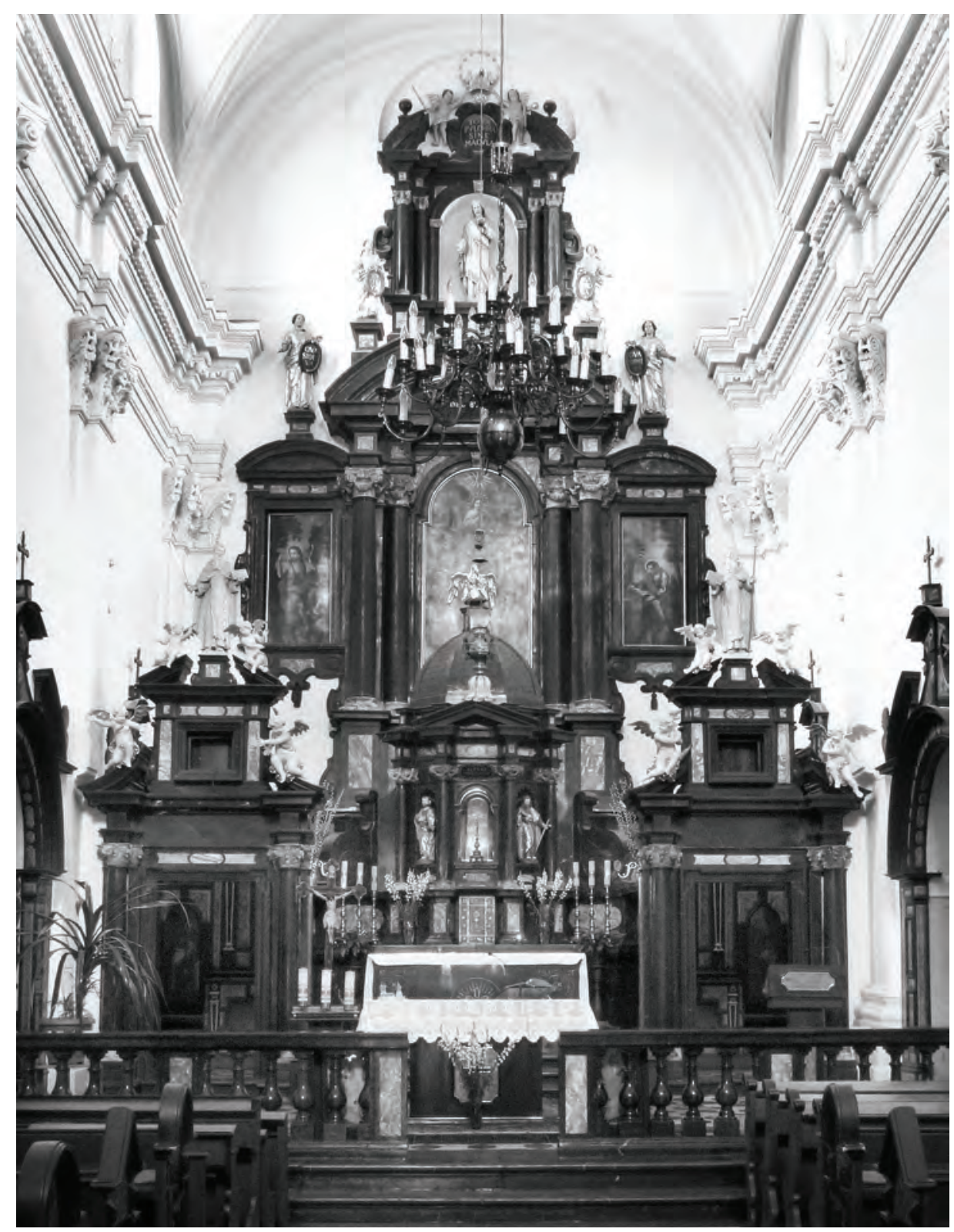

12. Michał Poman i Jakub Bielawski (wykonawcy), ołtarz główny kościoła karmelitów p.w. św. Łazarza $w$ Krakowie na Wesołej, 1683-1688, fot. J. Sito

świadczą pokwitowania $\mathrm{z}$ odebranych pieniędzy dokonane zarówno kamieniarzy (sic!), jak i przez samego Placidiego, a także przez przedsiębiorcę, mieszczanina $\mathrm{z}$ podkrakowskiego Kazimierza, niejakiego Jędrzeja Ziernickiego. Ten ostatni spławił fragmenty marmurowe Wisłą spod Krakowa do Kazimierza Dolnego, a dalej przewiózł podwodami do Lublina ${ }^{33}$. Dominikanie - jak pisze Wadowski

33 WADOWski 1907, s. 351, przypis 1. 
$39 \mid \begin{gathered}\text { TECHNE } \\ \text { TEX X H } \\ \text { SERIA NOWA }\end{gathered}$

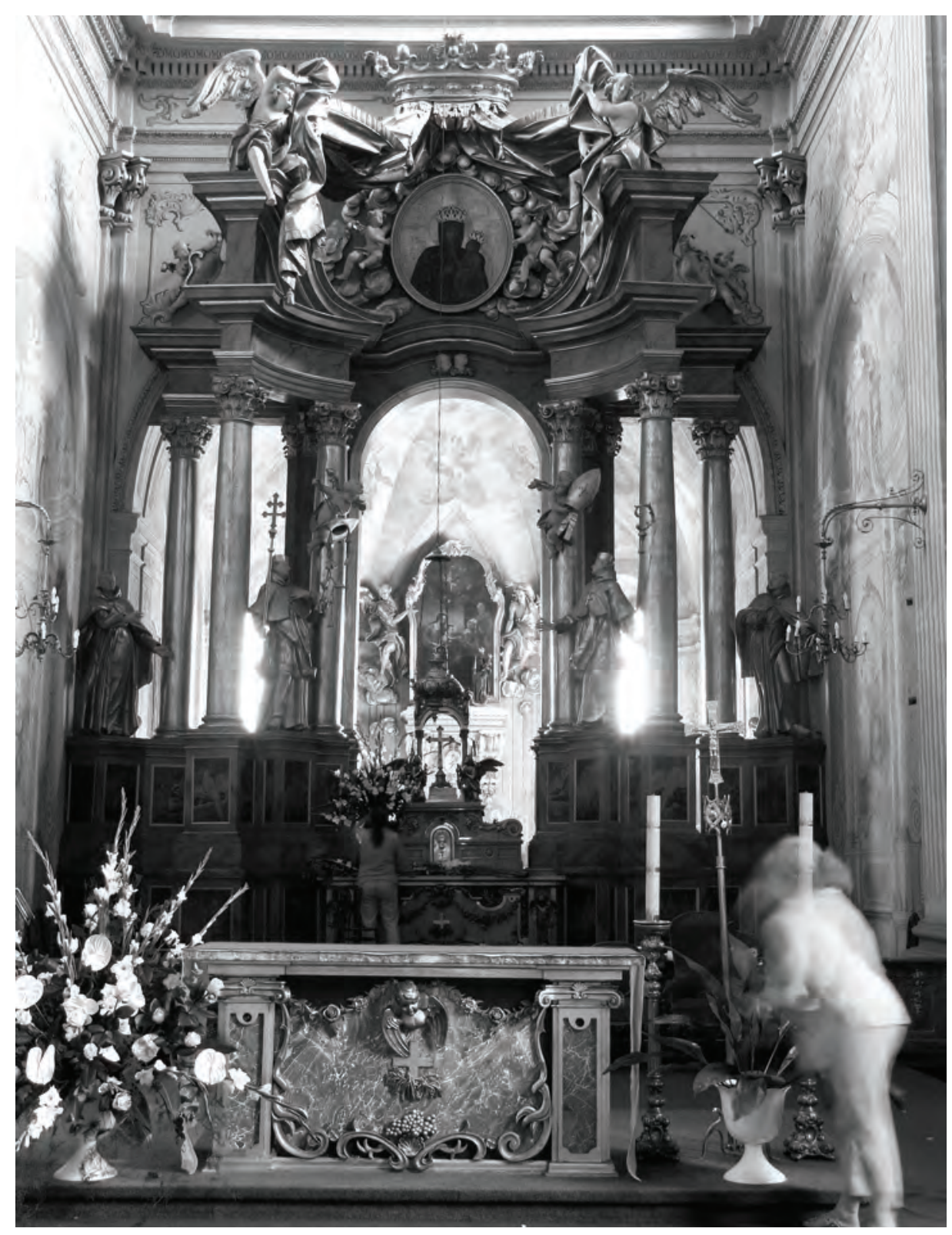

13. Carlo Antonio Bay (projekt), ołtarz główny kościoła bernardynów p.w. św. Anny w Warszawie, ok. 1730, fot. J. Sito

- zapłacili Tomaszowi Góreckiemu za wykonane elementy marmurowe w ratach: przy kontrakcie 4000 złotych polskich, dalej 8647 i 500, tak że razem dało to kwotę 13146 złotych $^{34}$.

Wadowski miał w swych rękach włoskie pokwitowanie Placidiego wydane w Krakowie 20 czerwca 1760 roku opiewające na 20 dukatów, jakie architekt miał

34 Tamże, s. 351, przyp. 1. 
odebrać od dominikanina o. Przewoskiego ${ }^{35}$. Czego dotyczył ów (dziś zaginiony?) dokument, nie wiemy; nie mogło chodzić raczej o projekt, który z reguły w ówczesnej Polsce kosztował mniej, a musiałby powstać przecież najpóźniej na początku roku 1760, o ile wręcz nie w roku 1742, być może chodziło zatem o nadzór nad pracą kamieniarza, odbiory prac tego ostatniego etc.

Inny dominikanin, o. Józef Zakrzewski, był oddelegowany dla przyjmowania marmurów w Kazimierzu Dolnym i ich wysyłki podwodami do Lublina. W jednym z listów wspominał, że odebrał na ołtarz „marmuru sztuk 101”36, a zatem rzeczywiście sprowadzano je do Lublina. Tymczasem, jak pisał A. Wadowski:

[choć] marmury z Kazimierza Dolnego sprowadzono do Lublina, [choć] już magistrzy mularscy byli sprowadzeni do wzmocnienia podstawy pod balustradę, stawiania mensy z portierami i wielkiego ołtarza, to $\mathrm{z}$ końcem 1763 i z początkiem 1764 roboty przerwano i nigdy nie były już ponowione ${ }^{37}$.

Póki co bez odpowiedzi pozostaje pytanie, dlaczego tak się stało. Ostatecznie, po kolejnych 30 latach, bo dopiero w 1794 roku, stanął w kościele zupełnie już inny, klasycystyczny ołtarz główny, stanowiący jakby echo retabulum Placidiowskiego, bowiem zaprojektowany został jako niska przegroda między prezbiterium a chórem zakonnym mieszczącym się w kaplicy Tyszkiewiczów, tym razem jednak już drewniany i znacznie prostszy ${ }^{38}$.

Jak zatem do powyższych, ustalonych archiwalnie dziejów zagospodarowania w XVIII wieku prezbiterium świątyni lubelskiej ma się nasz rysunkowy projekt ołtarza związany tu z Johannem Georgiem Plerschem? Czy rysunek ów powstał przed nawiązaniem kontaktów przez lubelskich dominikanów z Placidim i ostatecznym zatrudnieniem krakowskiego architekta? Przypomnijmy, iż pierwsza wzmianka na ten temat pochodzi już z 1742 roku. Warto też przypomnieć, że Placidi miał już wówczas bardzo konkretne wyobrażenie na temat kształtu ołtarza, który „miał być ustawiony pośrodku chóru” i wykonany „z marmurów krajowych”39. Jako że już w tym czasie był określony jego koszt, opiewający na ok. 50 tys. złotych, można mniemać, iż istniał już projekt tego dzieła lub choćby jego mniej lub bardziej ogólna koncepcja. Dlaczego do sprawy powrócono dopiero po 17 latach, tego nie wiadomo, być może zaważyły względy finansowe. Niemniej ciekawe jest pytanie, dlaczego ostatecznie powrócono właśnie do osoby Placidiego, choć swoje usługi na terenie Lublina i okolic oferowało w tym czasie co najmniej kilka prężnych ośrodków artystycznych. Poza Krakowem i najbliższymi ośrodkami magnackimi, jak Puławy czy Zamość, były to Lwów i przede wszystkim Warszawa.

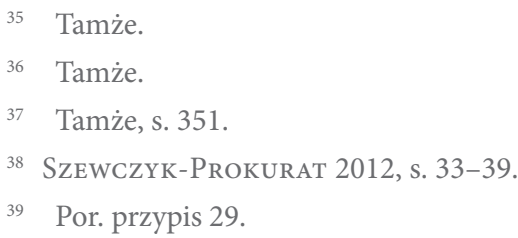


Ta ostatnia pojawiła się (jak starałem się wykazać) na jakiś czas w orbicie zainteresowań lubelskich dominikanów. Tym razem to nie architekt, a rzeźbiarz zaoferował swoje usługi. Plersch, artysta równie wybitny jak Placidi, miał tę przewagę, że mógł zapewnić kompleksowo potraktowaną usługę - od projektu do wykonania. Można też ostrożnie domniemywać, że całe przedsięwzięcie w jego rękach miało być tańsze - warszawskie ołtarze tego czasu, zwłaszcza te projektowane przez rzeźbiarzy, były bowiem wykonywane raczej z drewna (czasem murowane i kryte stiukiem) niż z marmuru. Absurdalnego kosztu 50 tys. złotych dzieło to żadną miarą nie osiągnęłoby, nawet u niezwykle ceniącego się królewskiego rzeźbiarza, jakim był Plersch. A jednak po latach powrócono do pierwotnego zamysłu budowy drogiego ołtarza marmurowego. Choć ostatecznie wydane nań pieniądze stanowiły kwotę znacznie mniejszą od „księżycowej” sumy 50 tys. (odnotowane wydatki opiewały, jak wskazywaliśmy, na sumę $13146 \mathrm{zt}^{40}$ ), to przedsięwzięcie i tak poniosło fiasko, i to mimo sprowadzenia już obrobionego budulca na miejsce.

Kiedy zatem pojawiła się konkurencyjna propozycja Plerscha? Mogło się to wydarzyć jedynie w przedziale 13 lat między pierwszym pojawieniem się Placidiego w konwencie lubelskim a jego finalnym zaangażowaniem. Terminus ante quem to rok 1760 , kiedy ostatecznie podpisano kontrakt $\mathrm{z}$ Tomaszem Góreckim na podstawie (nowego?) projektu Placidiego. Za terminus post quem należy uznać z kolei datę edycji Neufforge’owskich Nouveaux Livres des Autels et Baldaquins - rok 1747. Na pytanie natomiast, dlaczego konkurencyjna warszawska alternatywa nie okazała się dość atrakcyjna, w chwili obecnej - wobec niedostatku źródeł - nie sposób jednoznacznie odpowiedzieć.

\section{Bibliografia}

\section{Źródła rękopiśmienne}

Biblioteka Narodowa w WARsZAwie - Korespondencja Andrzeja Stanisława Załuskiego z roku 1742, t. 2 [L-Z], rkps 3223 III.

\section{Źródła drukowane i opracowania}

Bartczakowa 1970 - Aldona Bartczakowa, Jakub Fontana. Architekt warszawski XVIII wieku, Warszawa 1970.

Bohdziewicz 1954 - Piotr Bohdziewicz, Tomasz Dolabella a obrazy kaplicy Tyszkiewiczów w kościele oo. dominikanów w Lublinie, „Ochrona Zabytków”, t. 7, z. 4 (1954), s. 288-291.

40 Por. przypis 33. 
DęBı́́ski 1895 - Karol Dębiński, Drzewo Krzyża Świętego w kościele świętego Stanisława B. M., „Przegląd Katolicki”, t. 33 (1895), s. 449-452, 515-519.

DŁugosz 1860 - Jan Długosz, Liber beneficiorum Dioecesis Cracoviensis, Kraków 1860.

Eustachiewicz 1956-1957 - Janina Eustachiewicz, Fresk w kaplicy Św. Krzyża przy kościele oo. dominikanów w Lublinie, „Roczniki Humanistyczne”, t. 6, z. 4 (1956-1957), „Prace z Historii Sztuki”, s. 227-244.

GaJEwsKi 2012 - Jacek Gajewski, Nagrobek Jana Tarly w Warszawie i zagadnienia jego rekonstrukcji (mała architektura w twórczości Jakuba Fontany; Plersch i warsztat), „Arteria. Rocznik Wydziału Sztuki Politechniki Radomskiej”, nr 10 (2012), s. 58-91.

GAWARECKI 1959 - Henryk Gawarecki, Lublin - przewodnik, Lublin 1959.

KAPEć [bd.] - Waldemar Kapeć, Kościół i klasztor dominikanów w Lublinie, Lublin [bd.].

KŁoczowsKi 2006 - Jerzy Kłoczowski, Klasztor dominikański w Lublinie w pierwszych wiekach swego istnienia w ramach prowincji polskiej (stulecia XII-XVI), [w:] Dominikanie w Lublinie. Studia z dziejów i kultury, red. Henryk Gapski, Lublin 2006, s. 23-58.

Kossowski 1958 - Aleksander Kossowski, Lublin w latach „Potopu”, „Roczniki Humanistyczne”, t. 6, z. 5 (1958), s. 223-257.

Kowalczyк 1962 - Jerzy Kowalczyk, Architektoniczno-rzeźbiarskie dzieło Falconiego w Lublinie (kaplica Św. Krzyża przy kościele dominikanów), „Biuletyn Historii Sztuki”, t. 24, z. 1 (1962), s. $27-43$.

KowAlCzy 1992 - Jerzy Kowalczyk, Architektura sakralna między Wisła a Bugiem w okresie późnego baroku, [w:] Dzieje Lubelszczyzny, t. 6: Między Wschodem a Zachodem, cz. 3: Kultura artystyczna, red. Tadeusz Chrzanowski, Lublin 1992, s. 37-118.

LePiARCZy 1965 - Józef Lepiarczyk, Architekt Franciszek Placidi, ok. 1710-1782, „Rocznik Krakowski”, t. 37 (1965), s. 63-126.

Мiкоска-Raснuвowa 2003 - Katarzyna Mikocka-Rachubowa, Plersch Johann Georg, [w:] Słownik artystów polskich i obcych $w$ Polsce działajacych (zmartych przed 1966 r.). Malarze, rzeźbiarze, graficy, t. 8, Warszawa 2003, s. 276-283.

Mıєове̨Dzкi 1980 - Adam Miłobędzki, Architektura polska XVII wieku, Warszawa 1980.

Neufforge 1747 - Jean-François de Neufforge, Nouveaux Livres de plusieurs Projets d'Autels et Baldaquins, Paris 1747.

Oeuvres 1749-1751 - Oeuvres de Gilles-Marie Oppenord Ecuier Directeur General des Batiments et jardins de son Altesse Royale Monseigneur Le Duc d'Orleans Regent de Royaume (...), Paris 1749-1751.

PÉrouse 1995 - Jean-Marie Pérouse de Montclos, Histoire de l'architecture française, t. 2: De la Renaissance à la Révolution, Paris1995.

PréAud 1999 - Maxime Préaud, Inventaire du fonds français. Graveurs du XVIIe siècle, t. 12: Jean Lepautre, Paris 1999.

Rolska-Boruch 2010 - Irena Rolska-Boruch, Dzieje Krzyża Chrystusowego i legenda rodowa Tyszkiewiczów, [w:] Studia nad sztuką renesansu i baroku, t. 10, red. Irena Rolska-Boruch, Lublin 2010, s. 93-122.

RolsKa-BorUch 2012 - Irena Rolska-Boruch, Monstrancja krzyżowa z kościoła OO. Dominikanów w Lublinie, [w:] Ex voto. Studia dedykowane Ojcu Janowi Golonce OSPPE w 75. rocznice urodzin i $w$ 50. rocznicę święceń kapłańskich, red. Przemysław Mrozowski, Jerzy Żmudziński, Częstochowa 2012, s. 599-602.

Ruszel 1655 - Paweł Ruszel, Skarb nigdy nie przebrany Kościoła Świętego Katolickiego Krzyż Pański (...), Lublin 1655.

Siтo 1999 - Jakub Sito, Plastik und Austattung in Spätbarockraumkonzeptionen. Bemerkungen zu einer Gruppe der barocken Perspektivaltäre, [w:] Gartenskulptur, Plastik im Kontext der Architektur, red. Konstanty Kalinowski, Poznań 1999, s. 231-256. 
Siто 2013 - Jakub Sito, Wielkie warsztaty rzeźbiarskie Warszawy doby saskiej. Modele kariery - formacja artystyczna - organizacja produkcji, Warszawa 2013.

Siтo 2019 - Jakub Sito, Warszawscy rzeźbiarze czasów saskich w roli projektantów, artykuł złożony do druku w „Biuletynie Historii Sztuki”.

Szewczyк-Prokurat 2012 - Danuta Szewczyk-Prokurat, Klasztor w sercu miasta. Dzieje i skarby lubelskich dominikanów, Lublin 2012.

TAtARKiewiCz 1952 - Władysław Tatarkiewicz, Czarny marmur w Krakowie, „Prace Komisji Historii Sztuki”, t. 10 (1952), s. 79-152.

WADowski 1907 - Jan Ambroży Wadowski, Kościoły lubelskie. Na podstawie źródeł archiwalnych, Kraków 1907.

WojCiechowsкi 1995 - Leszek Wojciechowski, Sanktuarium Św. Krzyża w Lublinie. Problem genezy, [w:] Peregrinationes. Pielgrzymki w kulturze dawnej Europy, red. Hanna Manikowska, Hanna Zarembska, Warszawa 1995, s. 288-296.

Wojcıесношsкi 2006 - Leszek Wojciechowski, Dominikańskie sanktuarium Krzyża Św. w Lublinie do połowy XVII wieku, [w:] Dominikanie w Lublinie. Studia z dziejów i kultury, red. Henryk Gapski, Lublin 2006, s. 111-146.

Wyszomirska 2016 - Monika Wyszomirska, Fontana (Fontanna, Fontani) Jakub (Giacomo), [w:] Słownik architektów i budowniczych środowiska warszawskiego XV-XVIII wieku, red. Paweł Migasiewicz, Hanna Osiecka-Samsonowicz, Jakub Sito, Warszawa 2016, s. 131-137.

Wzonek 1971 - Józef Wzorek, Oprawy relikwii Drzewa Krzyża Świętego w kościele OO. Dominikanów w Lublinie, „Roczniki Humanistyczne”, t. 19, z. 5 (1971), s. 63-77.

Zieliński 1887 - Władysław Zieliński, Monografia Lublina. Kościół i klasztor OO. Dominikanów przy ul. Złotej i Dominikańskiej, Warszawa 1887. 


\section{Johann Georg Plersch's Previously Unknown Design of the High Altar in the Dominican Church in Lublin}

$\mathrm{T}$

he article is devoted to the design drawing for the monumental rococo high altar, recently discovered in the collection of the National Museum in Warsaw. A profound analysis of the drawing leads to a series of conclusions.

Firstly, its formal features: composition, forms, drawing technique (the brushstroke marks, the wash) indicate beyond any doubt that the drawing was made by Johann Georg Plersch (approx. 1700-1774) - a Warsaw-based sculptor at the courts of August II and August III, and one of the most prominent Warsavian artists of the epoch. Secondly, the drawing is the design for the high altar in the Dominican Church in Lublin, as evidenced by its proportions, the pieces of the existing architecture and the extremely distinctive iconography of symbolic and figural representations. The altar was devoted to the glorification of the Cross of Christ, whose glorious image is carried by angels and which is also paid homage to by the grand figures of Constantine the Great and Saint Helena, and above all else, the relics of the Holy Cross, stored in the peculiarly shaped $17^{\text {th }}$ century reliquary (well known to researchers of the Lublin temple) placed in the open arcade within the main body of the church. They are the main point of reference for the whole design, both in terms of ideology and composition. The subject matter of the paper is the drawing itself, with its interesting Warsavian, Roman and Parisian archetypes. The shrouded history of the commission placed for the construction of the stone altar, initially given to Cracovian masters (more precisely, to Francesco Placidi) and then assigned to Warsaw-based artists adds to the mystery, with the work never being installed in the intended location, i.e., in the presbytery of the Lublin church, at the exit of the Chapel of the Holy Cross (also known as the Tyszkiewicz chapel). Its stone elements were crafted and rafted along the Vistula River to Puławy, where it disappeared without a trace. 